\title{
An Assessment of the Challenges affecting Smallholder Farmers in Adopting Biogas Technology in Zambia
}

\author{
Thomson Kalinda ${ }^{1}$ \\ ${ }^{1}$ Department of Agricultural Economics \& Extension, University of Zambia, Lusaka, Zambia \\ Correspondence: Thomson Kalinda, Department of Agricultural Economics and Extension, University of Zambia, \\ Lusaka, Zambia. Tel: 260-966-454-366. E-mail: thomsonkalinda@gmail.com
}

Received: April 1, 2019

doi:10.5539/eer.v9n1p48

\author{
Accepted: May 3, 2019 Online Published: May 30, 2019 \\ URL: https://doi.org/10.5539/eer.v9n1p48
}

\begin{abstract}
The objective of this study was to assess the challenges of adopting biogas technology among rural households in Zambia. Three hundred and twenty households with and without biodigesters were selected randomly from five provinces in the country for the study. A household survey and qualitative methods such as focus group discussions and key interviews were used to collect information. The results show that firewood and charcoal are the main sources of cooking energy in the study areas despite the enormous potential for the utilization of biogas. The use of biogas technology is in its infancy and few households have adopted the technology. The study found that several challenges or factors were responsible for the low adoption status of biogas technology in the study areas. The main challenges were the high cost of installation of biodigesters; lack or limited access to credit to help meet the costs of construction of biodigesters; inadequate numbers of skilled biodigester technicians; and lack of awareness or limited information on biogas technology. Increasing access to affordable credit, as well as awareness raising on biogas technology among rural households are suggested as some of the ways that will assist to promote the adoption of biogas technology as a sustainable renewable energy source for rural populations in Zambia.
\end{abstract}

Keywords: sustainable renewable energy, biomass, biogas technology, biodigesters, Zambia

\section{Introduction}

In Zambia, woodlands and forests are estimated to cover about 50 million hectares, or 66 percent of the country's total land area. The main sources of wood fuel are natural woodlands and agricultural lands. Given the very low income levels and the abundance of wood resources, it is foreseen that wood fuel (firewood and charcoal) would continue to dominate Zambia's energy consumption. In 2007, it accounted for over $70 \%$ of total national energy consumption. Households accounted for about $88 \%$ of wood fuel consumption (GRZ, 2008). Cooking and heating are the major household uses of wood fuel. The 2000 Census of Population and Housing indicated that $60.9 \%$ of households used firewood for cooking and $24.3 \%$ used charcoal while only $13.8 \%$ used electricity. The census further showed that in rural areas, $87.7 \%$ use wood for cooking, $9.5 \%$ used charcoal and only $1.5 \%$ used electricity in 2000 (Central Statistical Office, 2004).

Although there is no immediate wood fuel crisis in most parts of Zambia, wood fuel can no longer be thought of as a renewable resource because consumption rates are overtaking sustainable yields as a result of inefficient production and use and increasing population. Woodlands meet both energy and non-energy needs. If current trends of woodland depletion continue an "energy crisis" that will affect the majority of the people is likely to occur in the near future. This is in addition to desertification, which is already threatening some parts of the country (GRZ, 2008).

While the developed countries are concerned about rising global prices and the urgent need to curb climate change, the developing countries are faced with the challenge of lack of access to clean and efficient energy (World Bank, 2011). An estimated two billion people worldwide continue to lack access to efficient clean energy services. To address this situation, international organizations like the United Nations Development Programme (UNDP) and the World Bank, called for all nations to put special emphasis on renewable sources of energy (UNDP, 1997; World Bank, 2011). Renewable energy sources such as biogas, hydropower, wind power, solar photovoltaics, ethanol and biodiesel, and geothermal energy for heat and grid electricity are currently in wide use in some regions and being introduced in some areas in developing countries like Zambia (Flavin \& Aeck, 2005; GRZ, 2008; PMRC, 2013; Kalinda and Chisanga, 2014). 
According to Flavin and Aeck (2005), the use of renewable energy like biogas provides many benefits. Biogas technology is considered as a sustainable renewable energy source that can be used for cooking, lighting, heating and power generation. It offers various benefits such as saving fuel wood and protecting forests as well as reduces expenditure on fuels. It further reduces household labour on time spent on cooking and improves hygienic conditions (Brown, 2006; Hazra, et al, 2013). The gas is produced through anaerobic digestion process, a biological process that happens naturally when bacteria breaks down organic matter of plant origin in environments with little or no oxygen. On smallholder farms, biogas is derived from anaerobic decomposition of livestock wastes-dung, urine and waste feeds (Hazra, et al, 2013). Biogas technology has been advanced around the world as a renewable energy by various organizations such as government agencies, international organizations and non-governmental organizations (NGOs).

The Zambian government has endeavoured to reduce dependence on biomass as a source of energy and enhance environmental conservation, human health and poverty reduction of rural households by promoting adoption of biogas technology as an alternative source of energy. This mandate has been emphasized in the energy policy and the national development plans which authorize the national government to plan and regulate the energy sector (GRZ, 2006; GRZ, 2008; GRZ, 2011). The adoption of biogas technology has been promoted by both government and NGOs in several parts of the country. One such organization is SNV (Netherlands Development Organization). With support from the Swedish International Development Cooperation Agency (SIDA), SNV has been implementing a renewable energy project called Energy for Agriculture (E4A) in the country from 2015 (SNV, 2013; SNV, 2015). The project aims to develop viable markets for productive biogas that will lead to improved livelihoods through increased savings on conventional fuel sources and income generation from the productive use of biodigester products - biogas and bioslurry (SNV, 2015). In addition to triggering consumer demand through promotion, awareness raising and access to finance; the project will also develop the supply of biodigesters and productive appliances through skills development and result based finance incentives, and create an enabling environment that supports market development. The project envisages contributing to the national aim of poverty reduction by improving livelihoods and quality of life of rural farmers; reducing impacts of biomass resource depletion; and supporting national goals of food production and livestock development.

The E4A project is being implemented in high potential areas such as Copperbelt, Central, Southern, Lusaka and Eastern provinces. The project mainly targets smallholder dairy farmers. These farmers have a high potential to adopt biogas technology through utilization of manure and other wastes. The rural areas were the project is operating are traditionally cattle keeping areas were dairy or milk production has been promoted by several government, private sector organizations and NGOs including SNV (SNV, 2015). According to the Ministry of Energy, 341,000 units of biogas digesters are currently operational in the country (cited in PMRC, 2013).

However despite the efforts by the Zambian Government and NGOs like SNV to promote biogas technology, adoption among households in the country has remained low. Traditional biomass still remains the country's main source of energy resulting in adverse environmental impacts. Firewood and charcoal accounts for more than $70 \%$ of energy consumption with $57 \%$ of the urban population and $97 \%$ of the rural population using traditional biomass (Central Statistical Office, 2012). Firewood is mostly used for cooking in rural areas while the main fuel used in urban areas is charcoal (Mwitwa and Makano, 2012). It is against this background that this study sought to establish the underlying reasons for the continued low adoption of biogas technology in Zambia. The overall objective of this study was to assess the challenges of adopting biogas technology among rural households in Zambia. The specific objectives were to determine the use of conventional energy sources among the rural households in the study areas; and to assess the challenges affecting farmers in adopting biogas technology in the study areas.

The rest of this paper is structured as follows. The methodology is presented in section 2 , followed by the results and discussion in section 3. The conclusions and recommendations are then presented in sections 4 and 5 respectively.

\section{Methodology}

\subsection{Description of the Study Area}

This study was conducted in Central, Copperbelt, Eastern, Southern and Lusaka Provinces of Zambia covering a sample of districts and stakeholders where SNV is implementing its E4A project. The project targets farmers with cattle, particularly dairy cattle. As was noted earlier, these farmers have the greatest potential to adopt biogas technology through utilization of manure and other wastes which are produced on their farms. The rural areas were the E4A project operates in are traditionally cattle keeping areas were dairy or milk production has been promoted by several NGOs including SNV. 


\subsection{Sources and Methods of Data Collection}

Both qualitative and quantitative data were collected by employing the following methods.

Secondary data collection - Previous studies and literature were reviewed to characterize energy consumption and production constraints. The purpose of the documentary or literature review was to collect relevant published data and information on the various conventional energy sources utilized by households and the biogas energy technologies that have been promoted by SNV and other organizations.

Household Survey - The household survey was aimed at gathering information on knowledge, awareness, and practices of energy use. For this purpose, a questionnaire was designed for administration to the respondents. The questionnaire was designed to capture relevant information such as household demographics, sources of energy including knowledge, practices, and attitudes towards conventional energy sources and biogas technology, as well as constraints to adoption of biogas technology. The survey targeted to interview beneficiary and non-beneficiary households. The beneficiary households are those who have directly benefited from the E4A project. Such benefits were in the form of having a biodigester constructed at their home, capacity building and so forth. SNV had started implementing the E4A project in 2015 by constructing biodigesters and hence very few households had fully started to benefit from this technology at the time the survey was conducted in 2016.

The sample size for the household survey was determined by using the relevant statistical formulae. The sample size was determined by employing Cochran's general formula for sample calculation, which is the relevant statistical formulae in this case (Bartlett, et al, 2001). Cochrane's general formula for sample size is expressed as:

$$
n=\frac{Z^{2} p(1-p)(D E F F)}{d^{2}}
$$

Where $\mathrm{n}$ is the estimated sample size

$\mathrm{Z}=1.96$ from a standard distribution table at $95 \%$ confidence level

$\mathrm{P}=$ proportion of beneficiaries expected to adopt the new agricultural technologies $(0.8)$

$\mathrm{Q}=1-\mathrm{P}$ (those who will not adopt the new agricultural technologies) (0.2)

$\mathrm{d}=$ the level of error term which we are going to accept/tolerable $(0.05$ or $5 \%)$

DEFF (Design effect): the baseline survey did not use simple random sampling; rather it applied a multi stage sampling technique. It is a ratio of variance using a given sample design to the ratio of variance assuming simple random sampling and applied as an adjustment factor, 1.2 (USDA, 2014).

Substituting for the above values in the formula:

$$
n=\frac{1.96^{2} \times 0.8 \times 0.2(1.2)}{.05^{2}}=295
$$

Assuming that all small-holder farmers were not available during the survey, sampling with replacement was done for $10 \%$. So, this increased the sample size to 325 smallholder farmers.

Once the number of sample households were estimated, the next step was determining the sampling procedure. In general, the survey employed a two-step sampling procedure. During the first step, all eleven districts were selected from among the districts which are part of the E4A project areas.

During the second step, all Dairy Cooperatives or Milk Collection Centres within the selected 11 districts were identified. Cooperative membership lists were used as sampling frames from which dairy farmers were randomly selected. During this stage of the sampling procedure, households with dairy livestock within the selected cooperatives/milk collection centers were selected using a systematic, random sampling technique. Since the E4A project is dairy livestock focused, the ultimate target group of the survey were households which had some dairy animals. The final sample consisted of 320 households as shown in Table 1. 
Table 1. Sample Distribution by District

\begin{tabular}{llll}
\hline Province & District & Number & \% \\
\hline Central & Chibombo & 40 & 12.5 \\
Copperbelt & Luanshya & 40 & 12.5 \\
Eastern & Chipata & 20 & 6.3 \\
Lusaka & Chilanga & 20 & 6.3 \\
& Chongwe & 40 & 12.5 \\
Southern & Choma & 40 & 12.5 \\
& Mazabuka & 20 & 6.3 \\
& Monze & 20 & 6.3 \\
& Zimba & 20 & 6.3 \\
& Namwala & 40 & 12.5 \\
& Livingstone & 20 & 6.3 \\
\hline Total & & $\mathbf{3 2 0}$ & $\mathbf{1 0 0 . 0}$ \\
\hline
\end{tabular}

The sample included both the E4A project beneficiaries and the non-beneficiaries. This was important for this study because this provided adequate information on the emerging changes in knowledge, awareness, and practices of energy use in the communities given that biodigester or biogas utilization is a relatively new technology in some areas.

Focus Group Discussions - Focus group discussions (FGDs) with farmers or household heads were also conducted. The discussions were guided to address the relevant study issues using a checklist. Discussions with these respondents were important in understanding the households' decision-making and actions with regards to the types of energy consumed. The information collected during the focus group discussions were a means of triangulating the information that were collected from the household survey. Focused group discussions with the few beneficiaries and non-beneficiaries were also important in presenting a comprehensive analysis or assessment to fully understand the energy issues as well as the constraints or barriers to adoption of biogas as an energy source in the study communities.

Key Informant Interviews - Key informant interviews involving in depth discussions with people and organizations with diverse knowledge of the various energy sources were conducted using an interview guide or checklist to direct discussions. Some of the key informants interviewed include SNV project facilitators or partners, Ministry of Agriculture and Livestock staff, biodigester technicians or masons, farmers, group or cooperatives leaders. The interviews with these key informants helped to assess the market in terms of various aspects such as the supply and demand for the biodigesters; and the constraints experienced in the adoption of biogas technology among the farmers.

\subsection{Data Analysis}

Upon completion of the interviews in the field, the questionnaires were coded and entered using CSPro software package. This data was cross checked for accuracy. The data was then exported to SPSS for analysis. Frequency tables were then used to discern tendencies and cross tabulations were also used to understand some patterns in some of the variables.

The information collected from the key informant interviews and focus group discussions was analyzed in accordance with the various themes that were covered. The analysis allowed for synthesis to enable drawing out key issues from the themes so that they are clearly and concisely extracted. This was then presented in a descriptive-analytical way in the relevant sections of the paper.

\section{Results and Discussion}

\subsection{Socio-demographic Characteristics of the Households}

The descriptive statistics of the sample households are presented in Table 2. The overall sample comprised about $10 \%$ female headed and $90 \%$ male headed households. With respect to marital status, $79 \%$ of the household heads were married, $11 \%$ were widowed and about $4 \%$ were either divorced or separated, and $6 \%$ were single. Age has an impact on the productive capacity of smallholder farmers. The estimated mean age of the households in the sample is about 46 years. This age profile means that the majority of the household heads were people predominantly below midlife and could be regarded as potentially productive farmers with capacity to adopt new energy technologies like biogas and other farming practices. 
Table 2. Descriptive Statistics of Sampled Households

\begin{tabular}{l|ll}
\hline Age Category & Total (N) & \% \\
\hline $12-17$ & 1 & 0.3 \\
$18-40$ & 54 & 16.9 \\
$41-59$ & 181 & 56.6 \\
60 and above & 84 & 26.2 \\
Total & $\mathbf{3 2 0}$ & $\mathbf{1 0 0 . 0}$ \\
\hline Educational Background & $\mathbf{N}$ & Total (\%) \\
\cline { 2 - 3 } Never Went to School & 19 & 5.9 \\
Primary School (Grade 1-7) & 77 & 24.1 \\
Junior High School (Grade 8-9) & 68 & 21.3 \\
Senior High School (Grade 10-12) & 84 & 26.3 \\
College and Above & 72 & 22.5 \\
Total & $\mathbf{3 2 0}$ & $\mathbf{1 0 0 . 0}$ \\
\hline Marital Status & $\mathbf{N}$ & $\mathbf{\%}$ \\
Single & 18 & 5.7 \\
Married & 253 & 79.1 \\
Divorced & 10 & 3.2 \\
Separated & 4 & 1.2 \\
Widowed & 35 & 10.8 \\
\hline Total & $\mathbf{3 2 0}$ & $\mathbf{1 0 0 . 0 .}$ \\
\hline
\end{tabular}

Furthermore, about $94 \%$ of those interviewed had some formal education. Of these, $24 \%$ had primary education and $21 \%$ had junior secondary education and $26 \%$ had senior secondary education. About $23 \%$ reported that they had post-secondary education. About $6 \%$ reported having no formal education. The results in Table 2 indicate that a good number (94\%) of household heads in the study at least have attained some formal level of education while a few are highly educated. With such high levels of education many respondents may be in a position to internalize and understand technical terms that may be used in biogas technology awareness or training sessions. This positively affects their ability to adopt the new technology and they may be willing to accept the technology. These results concur with studies elsewhere which find that high levels of education/literacy act as a support in technology adoption.

The average family size of the sampled households is 12 people per household which is higher than the national average household size of 6 (CSO, 2012). The large household sizes are partly as a result of polygamy, and levirate marriages or widow inheritance which are common customary practices in rural areas in Zambia (Kalinda and Tembo, 2010). Table 3 shows the distribution of households according to age groups and gender composition.

Table 3. Distribution of Households by Age group \& Gender

\begin{tabular}{lllllllll}
\hline Household Size & $\begin{array}{l}\mathbf{0 - 5} \\
\text { year } \\
\text { Males }\end{array}$ & $\begin{array}{l}\mathbf{0 - 5} \text { year } \\
\text { Females }\end{array}$ & $\begin{array}{l}\mathbf{6 - 1 7} \\
\text { year } \\
\text { Males }\end{array}$ & $\begin{array}{l}\mathbf{1 8 - 5 9} \\
\text { year } \\
\text { Males }\end{array}$ & $\begin{array}{l}\mathbf{1 8 - 5 9} \\
\text { year } \\
\text { Females }\end{array}$ & $\begin{array}{l}\text { 60 years } \\
\text { \& above } \\
\text { Males }\end{array}$ & $\begin{array}{l}\text { 60 years \& } \\
\text { above } \\
\text { Females }\end{array}$ & $\begin{array}{l}\text { Average } \\
\text { Household } \\
\text { Size }\end{array}$ \\
\hline Female HH & 1.22 & 1.43 & 2.07 & 2.13 & 2.15 & 1.00 & 1.13 & 11.14 \\
Male HH & 1.95 & 1.84 & 2.46 & 1.99 & 2.00 & 1.03 & 1.13 & 12.40 \\
Total & $\mathbf{1 . 9 1}$ & $\mathbf{1 . 8 2}$ & $\mathbf{2 . 4 4}$ & $\mathbf{2 . 0 0}$ & $\mathbf{2 . 0 1}$ & $\mathbf{1 . 0 3}$ & $\mathbf{1 . 1 3}$ & $\mathbf{1 2 . 3 4}$ \\
\hline
\end{tabular}

Most rural households depend on family labour for various farm activities and therefore, the size of the household has an impact on labour supply. The size of the household for the sample household ranges from 1 to 20 members. This is an indication of sufficient labour to run biogas plant operations and it could be an inspiration for households to adopt biogas. Similar findings reported by Momanyi et al. (2016), found that excess labour influenced positively households' willingness to adopt biogas. Household labour is an important factor in adoption of biogas plants. The biogas plants require collection of cow dung, water, mixing the dung with water, feeding the plant, cleaning the cow shed and transporting the slurry to the farm. Without enough people in the family to carry out all of the above activities it is difficult for biogas plants to run efficiently. 


\subsection{Household Livelihood Strategies}

Rural households engage in various livelihood strategies to earn a living. The respondents were asked to indicate what they considered to be major activities that are sources of income for their households. The results as seen in Table 4 show that the households depend mostly on agriculture for their livelihoods. On-farm income comes from the sale of both food and cash crops (grains, fruits and vegetables), as well as livestock products. Off-farm income includes cash income from both agricultural work and non-agricultural activities like charcoal burning and sales, piece work (seasonal or part-time), formal employment, petty trading, remittances and others.

Table 4. Percentage Distribution of Households by Main Source of Income

\begin{tabular}{lll}
\hline Source of Income & N & \% \\
\hline Cattle rearing & 61 & $19 \%$ \\
Sale of rain-fed cash crops & 54 & $17 \%$ \\
Local chicken rearing & 51 & $16 \%$ \\
Goat rearing & 42 & $13 \%$ \\
Gardening activities/Off season farming & 38 & $12 \%$ \\
Sale of rain-fed food crops & 32 & $10 \%$ \\
Remittances & 16 & $5 \%$ \\
Petty trading & 10 & $3 \%$ \\
Piece work & 6 & $2 \%$ \\
Sale of Charcoal & 3 & $1 \%$ \\
Other Sources & 6 & $2 \%$ \\
\hline Total & 320 & $100.0 \%$ \\
\hline
\end{tabular}

\subsection{Conventional Energy Use among the Sample Households}

Firewood (79\%) and charcoal (34\%) ranked highest as sources of energy used for cooking. Electricity was mentioned by only $9 \%$; agricultural wastes by $3.8 \%$; and LPG by $2.5 \%$; and kerosene by $1 \%$ (see Table 5). On average, the respondents use their conventional stoves for 4 hours per day for cooking. The huge consumption of biomass energy, especially charcoal and firewood for cooking is not surprising.

Total 5. Distribution of Households by the types of Fuel used for Cooking \& Lighting (Multiple response)

\begin{tabular}{lll}
\hline \multicolumn{3}{l}{ Fuels used for Cooking } \\
\hline Fuel & $\mathbf{N}$ & $\mathbf{\%}$ \\
\hline Firewood & 252 & $78.8 \%$ \\
Kerosene & 4 & $1.3 \%$ \\
LPG & 8 & $2.5 \%$ \\
Charcoal & 108 & $33.8 \%$ \\
Electricity & 28 & $8.8 \%$ \\
Agricultural waste & 12 & $3.8 \%$ \\
Other & 8 & $2.5 \%$ \\
\hline Fuels used for Lighting & \\
\hline Fuel & $\mathbf{N}$ & $\mathbf{\%}$ \\
\hline Kerosene & 4 & $1.3 \%$ \\
Electricity & 32 & $10.0 \%$ \\
Candles & 44 & $13.8 \%$ \\
Dry Cells & 80 & $25.0 \%$ \\
Other & 132 & $41.3 \%$ \\
\hline \multicolumn{2}{r}{} &
\end{tabular}

In the case of charcoal, most of the consumption takes place in the urban areas and the rural areas remain mostly as production sites. The majority of people in the rural areas use firewood as their main energy source for cooking in their households, in their small businesses and other activities. Plant residues or agricultural wastes were also mentioned as a source of energy. However, very little is done to purposely cater for its use as an important source of energy. Plant residues are usually limited to the harvest seasons and it is during this time that people replace 
firewood with plant residues as a source of domestic energy.

When asked to identify their main sources of energy used for lighting, $25 \%$ of the respondents mentioned dry cells; $14 \%$ candles; $10 \%$ electricity and $1.3 \%$ kerosene. In terms of lighting, the majority out of the $41 \%$ that indicated use of other sources likely rely on generators, batteries, or solar energy. It is common to find generators, batteries and candles being used for lighting as well as to power devices like televisions and radios for entertainment. Cooking and lighting are the major uses of the conventional energy sources. A majority (97\%) of the households reported that they do not use the conventional energy sources for any other purpose apart from cooking and lighting.

\subsection{Availability of Energy Sources in the Community}

The respondents were also asked to indicate the sources of the conventional energy they utilize and their availability in their communities. Table 6 below shows energy sources available to the sample households in their communities. The results in the Table clearly show that the main fuel type available and collected is firewood which is mainly collected from local forests, own land or other sources. The households (68\%) predominantly cut twigs and dry branches for their firewood and another (25\%) cut down whole trees. On average, they collect about $82 \mathrm{~kg}$ of firewood per day per household. In the case of kerosene, which is mainly used for lighting, the people in households take an average of about 3 hours travel time to trek to the market where the fuel is sourced. This is expected given the dispersed or thin markets, particularly, petrol filling stations where kerosene is sold.

Table 6. Sources of Fuels for Households

\begin{tabular}{lcc}
\hline Source of fuel & $\mathbf{N}$ & $\mathbf{\%}$ \\
\hline Buy from vendors & 80 & $25.0 \%$ \\
Collect from local forest/own land/other sources & 144 & $45.0 \%$ \\
Both 1 \& 2 & 80 & $25.0 \%$ \\
No response & 16 & $5.0 \%$ \\
\hline Total & 320 & $100.0 \%$ \\
\hline Source of firewood if collected from local forest & & \\
\hline Source of firewood if collected from local forest & $\mathbf{N}$ & $\mathbf{\%}$ \\
\hline N/A & 24 & $7.5 \%$ \\
Cutting the whole tree & 80 & $25.0 \%$ \\
Cutting twigs and dry branches only & 216 & $67.5 \%$ \\
\hline Total & 320 & $100.0 \%$ \\
\hline
\end{tabular}

\subsection{Opinion on availability of Conventional Fuels}

The survey attempted to ascertain how difficult it is to collect and transport conventional sources of fuel for cooking on a day to day basis. As shown in Table 7, the respondents expressed concerns that the collecting and transportation of biomass energy (mainly firewood and charcoal) has become difficult in recent years. For instance, about $58 \%$ of the respondents felt that collecting of biomass energy has become difficult compared to the past. In other words, sources of fuelwood or charcoal have become scarce. About $29 \%$ indicated that in the past, collection of biomass energy was not difficult.

Table 7. Challenges in collection and transportation of conventional sources of fuel for cooking

\begin{tabular}{lll}
\hline $\begin{array}{l}\text { Do you think collection and transportation of conventional sources of fuel for cooking } \\
\text { getting difficult day by day? }\end{array}$ & $\mathbf{N}$ & $\mathbf{\%}$ \\
\hline No, it's not a problem & 24 & $7.5 \%$ \\
It was not a problem before & 92 & $28.8 \%$ \\
Yes it is a problem & 184 & $57.5 \%$ \\
Not applicable & 20 & $6.3 \%$ \\
\hline Total & 320 & $100.0 \%$ \\
\hline
\end{tabular}

In the past, wood fuel used to be a free or low cost energy source that was easily available in the communities. Today, wood fuel is no longer as accessible since all the natural forests have been encroached on, so people now have challenges in fetching wood fuel or even burning charcoal. The few forests that exist are owned privately. As can be seen above in Table 6, the households (45\%) source the wood fuel from their own farm land and from 
community forests which are getting depleted quickly due to heavy demand for energy resources. This lack or reducing availability of firewood and charcoal has mainly been attributed to factors such as the selling of traditional and communal land to private entities who have since forbidden the cutting of trees on their properties. In cases where land is not sold, forests are depleting making the firewood collection process more tedious and time consuming. The hydro-power shortage in the country which has resulted in load shedding is another factor that has added pressure on the availability and pricing of wood fuel. In the past, charcoal price increases were seasonal. In the rainy season when the commodity was difficult to produce, both prices and availability were affected. In recent times, non-availability and hiked prices are a norm due to the constant demand from urban consumers.

Given the major challenges currently being faced with the increasing cost and scarcity of conventional wood fuel, the study tried to assess the respondents' interest or willingness to get substitutes for the conventional sources of fuel. Respondents were asked about their opinion on the best alternative sources of energy to replace the conventional fuel sources for cooking and lighting. The results clearly show that the majority (91\%) households are interested/willing to get substitutes for the conventional sources of fuel because they are expensive and difficult to obtain. A majority ( $84 \%$ ) households were of the opinion that biogas is the best alternative source of energy to replace the conventional fuel sources used for cooking and lighting.

\subsection{Knowledge about Biogas Technology among the Sample Households}

This study was also interested in having an understanding of the sample households' knowledge about biogas technology and its benefits. Biogas technology is a fairly new technology in most communities. Even if this is the case, most respondents (49\%) admit having heard about it. Similarly, about $48 \%$ of the respondents were aware that cattle dung and urine could be used in biodigesters to produce biogas which can be used for cooking and lighting. Another relatively large number (32\%) mentioned that they have just partly heard about biodigesters and their benefits. Only 19\% indicated that they have not heard about biodigesters.

Among the respondents who indicated that they know or have heard about the biogas technology, they were further asked if they know the main benefits derived from the technology. Table 8 results show the level of awareness of the benefits of using biogas among the survey households. It is clear from Table 8 that the respondents know about the economic, social, environmental, and health benefits of using biogas produced from the biodigesters.

Table 8. The main benefits of using Biogas (Multiple response)

\begin{tabular}{lll}
\hline $\begin{array}{l}\text { If you have heard about the biogas technology, what are the main benefits of using the } \\
\text { technology? }\end{array}$ & $\mathbf{N}$ & $\mathbf{\%}$ \\
\hline Smoke-free cooking environment & 172 & $53.8 \%$ \\
Free from laborious collection of conventional fuels & 44 & $13.8 \%$ \\
Health benefits & 52 & $16.3 \%$ \\
Environmental benefits & 40 & $12.5 \%$ \\
Economic benefits & 24 & $7.5 \%$ \\
Saves time and energy & 20 & $6.3 \%$ \\
Social benefits/Prestige & 4 & $1.3 \%$ \\
Not applicable & 61 & $19.0 \%$ \\
\hline
\end{tabular}

Ease-of-use of biogas with a smoke free cooking environment (54\%) or no major health side effects (16\%) are benefits which most households, are particularly appreciative. Wood fuel which is normally used in open fires, is not very easy to use, and is generally not safe. It also poses additional problems depending on the season or time of year. Since both firewood and charcoal are stored outside in most cases, during the rainy season these get wet and become very difficult to light up. When finally lit up, they produce a lot of smoke which affects the eyes (itching and redness) and causes a lot of coughing. The problem of household members encountering any smoke borne diseases such as dizziness, eye-burning or respiratory infections was confirmed by the respondents. About $40 \%$ of the households are affected by this problem which is mainly due to the burning of wood fuels. Adult females (41\%) are affected the most since they are the ones who do the cooking in the households

The respondents (14\%) also mentioned that use of biogas energy helped to reduce the amount of time spent fetching for wood fuel. Reduced expenditure on energy ( $8 \%$ ) is also a major benefit of using biogas energy at the household level among the respondents. According to Lekule (1996), consumption of wood fuel could be reduced by up to $60 \%$ if biogas energy is used at the household level. Biogas use is therefore seen as a solution to help reduce expenditure on conventional energy costs. The reduced expenditure on energy helps to strengthen the households' 
economy thus providing more money for other essential expenditure items such as food, school fees, clothing and other income generating activities. This forms an important reality that can be used in the promotion of biogas technology.

Use of biogas technology also produces environmental benefits in that biogas replaces firewood, charcoal or kerosene as sources of cooking or lighting fuel. This saves natural wood reserves from being cut down and burnt. Conservation of the trees prevents soil from being eroded by heavy rainfall. Some of the households are also aware of the benefits of using bio-slurry, in managing soil fertility (13\%).

\subsection{Sources of Information about Biogas Technology}

Access to information that creates awareness or knowledge about biogas can greatly influence the adoption of biogas and other energy technologies. The study tried to assess the sources of information on biogas among the sample households who have heard about the technology. Table 9 below shows the sources of information about biogas technology which the households utilized.

Table 9. Source of Information about Biogas Technology (Multiple Response)

\begin{tabular}{lll}
\hline How did you know about Biogas technology? & $\mathbf{N}$ & $\mathbf{\%}$ \\
\hline Through publicity media & 32 & $10.0 \%$ \\
Through government officials & 24 & $7.5 \%$ \\
Through service providers/BCEs/Masons & 80 & $25.0 \%$ \\
Through friends/relatives & 68 & $21.3 \%$ \\
Through other biodigester owners & 12 & $3.8 \%$ \\
Through NGO/CBO personnel & 36 & $11.3 \%$ \\
Other & 4 & $1.3 \%$ \\
Not applicable & 92 & $28.8 \%$ \\
Through community leaders & 4 & $1.3 \%$ \\
\hline
\end{tabular}

From Table 9 above, service providers, biogas construction entrepreneurs (BCEs) and masons (25\%), and NGO staff $(11 \%)$ who include SNV staff were mentioned as important sources of information on biogas technology. It was mentioned that the SNV staff had conducted some awareness meetings on biogas in some parts of the communities. Relatives or friends $(21 \%)$ who have adopted biogas technology also comprise an important source of information in most instances because they easily share information as well as visit each other to see for themselves. Publicity media (10\%) and public officials like Extension officers $(8 \%)$ are also an important source as they often interact with farmers to conduct training sessions where they share new information relevant to farmers such as the biogas technology. Some masons sometimes work hand in hand with extension officers in order to create awareness about biogas technology. Other information sources about biogas include cooperative societies and local leaders $(1.3 \%)$

\subsection{Challenges Affecting Adoption of Biogas Technology among the Rural Households}

Despite having heard about biogas technology, only a few of the respondents admitted having gone further to adopt it. Survey results show that only 24 respondents or $7.5 \%$ indicated that they have fully adopted the technology while 296 respondents or $92.5 \%$ have not adopted. This low level of adoption was attributed to a number of factors as indicated in Figure 1 below.

The study showed that several challenges or factors were responsible for the low adoption status of biogas technology in the study areas. The main challenges were the high biodigester installation costs (75\%); lack or limited access to credit (72\%); inadequate numbers of skilled biodigester technicians (46\%); lack of awareness or limited information on biogas technology (26\%); lack of interest in biogas technology (4\%). A minority of the farmers $(2 \%)$ indicated that labour shortages in there households for operating the biodigesters were barriers that have hindered adoption of the technology. 


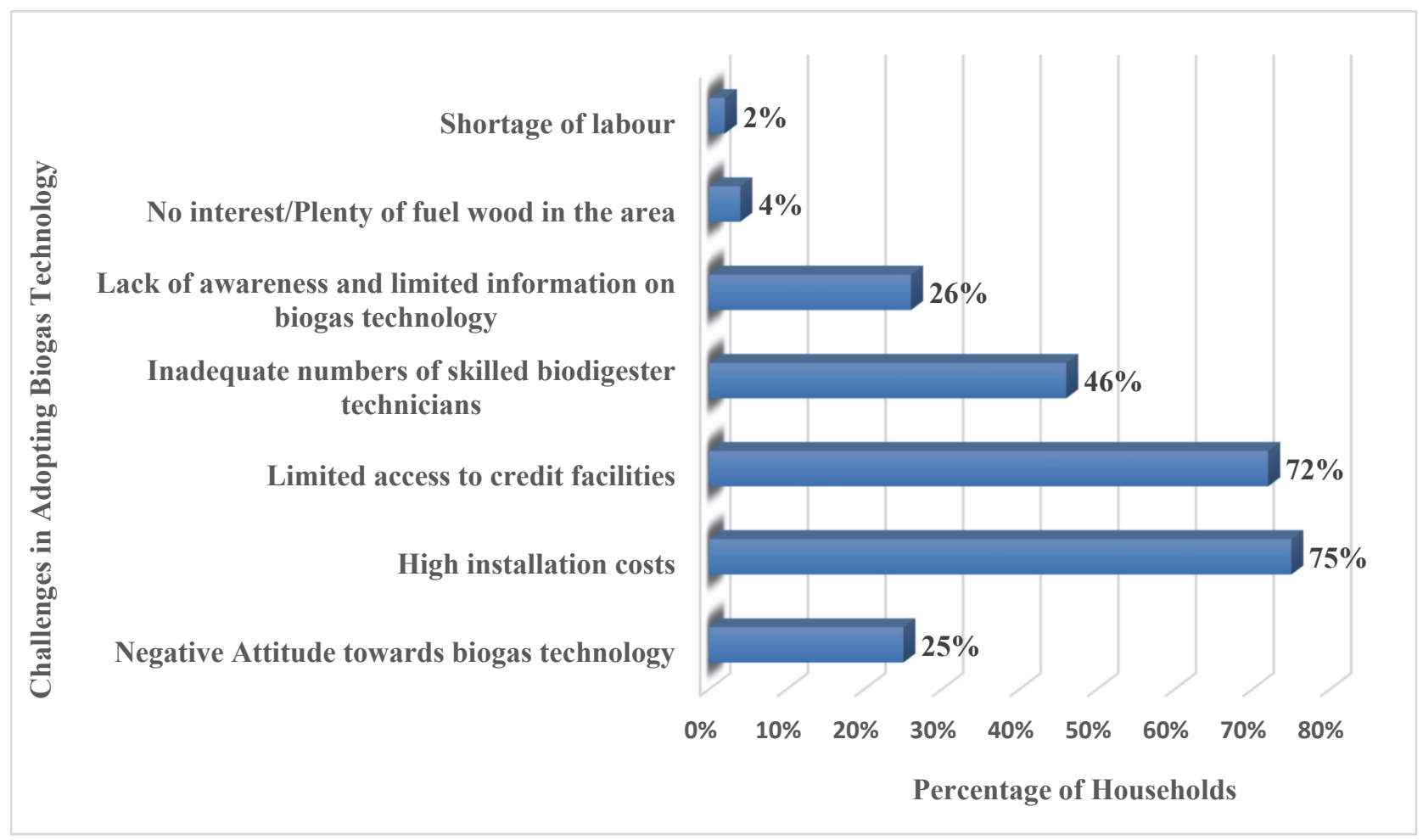

Figure 1. Challenges faced by sample household in Adopting biogas technology (multiple response)

\subsubsection{High Biodigester Installation Costs}

In both the survey and FGDs, the majority of the farmers (75\%) were of the view that the high upfront cost of installing biogas units was one of the major barriers that has hindered adoption among potential biogas users in the study areas. According to Quadir et al., (1995), high investment costs in installing biogas units have be blamed for the low adoption rates in many developing countries. This study established that both the perceived cost and actual costs acted as barriers to the adoption of the biodigester technology. It was noted during the study that the installed demo plants in some rural communities were mid to high-end $\left(12 \mathrm{~m}^{3}\right.$ and above) with costs ranging from ZMW30, 000 (Note 1) and above (according to the interviewed informants). The potential adopters have as a result perceived the cost to be in that range for all available biodigesters. However, farm households can have smaller biodigesters constructed at less than ZMW 30, 000. The cost of a family sized biodigester that produces enough gas to meet the cooking demand of a family ranges from ZMW 7,000 to ZMW 15,000.

\subsubsection{Limited Access to Credit Facilities}

According to the respondents in the FGDs, the high initial cost and lack of credit financing arrangements have hampered the uptake of biogas technology among the farm households. Farmers find it difficult to access loans especially for the purpose of agricultural or energy investments such as for meeting the costs of constructing a biodigester. Some of the survey households $(10 \%)$ are able to show how capital injections through dairy animals or seed and fertilizers boosts their profitability and thus enables them to pay back loans. However, it is not so easy to obtain loans. The terms and conditions demanded by lending institutions to secure their loans are unattainable to most smallholder farmers. The main challenges or constraints are the high interest rates charged (average 19\%); and the reluctance of credit organizations to lend to smallholder farmers who lack collateral in form of title for the land they own.

This may suggest that if the lending institutions or local micro-finance institutions provided low interest loans for biogas procurement, many households in the study areas could adopt biogas technology. If some local microfinance institutions or commercial banks can make credit available, with subsidized interest rates, some farm households are highly likely to get credit for construction of biodigesters. The survey showed that the majority farm households (79\%) would be interested in taking a loan to install a biodigester if credit is available.

\subsubsection{Inadequate Numbers of Skilled Biodigester Technicians}

The limited availability of well trained and skilled biogas masons or technicians was another barrier attributed to 
the low adoption status in the study areas. According to the FGDs, the few skilled biogas masons or technicians were based in the District centers such as Choma, Namwala or Monze and this increases transaction costs for farmers who require the services of these technicians in construction and maintenance the biodigesters. Most farmers observed that due to lack of locally trained biogas technicians, adoption of biogas technology in their communities has remained low. For increased adoption of biogas technology to occur, there is need to have sufficient numbers of trained masons or artisans at the local level who can construct and provide quality services for any interested clients at a reasonable cost. If sufficient numbers of local people are trained in biogas installation, operation and maintenance skills, then the adoption rates would increase in the study areas.

\subsubsection{Lack of Awareness and Limited Information on Biogas Technology}

Lack of awareness and limited information on the benefits and potential of biogas technology among some of the farmers is another major hurdle faced by the extension agents in their biogas extension services. During this study, most respondents in the survey and FGDs had limited knowledge about biogas technology.

This lack of awareness however varied in degree and in context depending on the area or district. For example, in areas where no sensitization of the technology has ever been done, farmers and other participants in the study, were hearing of the technology for the first time. Naturally the reason for not adopting the technology in such areas is that people have never heard of it.

Research participants acknowledged the presence of sensitization programs and messages communicated on health, energy and the environment (among other things). This is mainly done through churches, village meetings, cooperatives and radio. It was noted however, that energy related messages mostly focus on promoting the use of other alternative energy sources such as solar energy. Biogas technology is not promoted in most of the communities.

In areas where biogas has been introduced and demo plants installed, lack of knowledge is in the form of farmers not knowing the procedure to follow in order to build or acquire a biodigester. While farmers acknowledge and appreciate the technology, details on the cost, availability of the equipment, materials required and general technical guidance needed for one to get started is not readily available. Farmers housing demo plants appear to be well versed and able to promote the benefits of the biodigester technology, but fail to provide the details needed for potential adopters to actually acquire the technology. Referrals to masons have often proved futile as these are not easily reachable. In Chisamba and Luanshya, farmers have gone as far as registering their names at Milk Collection Centres, which is the only reference point they have, to show their interest and willingness to buy the equipment.

According to Bhat et al., (2001), lack of awareness of the value of biogas has been attributed as an inhibiting factor in the uptake of this technology in India. This supports the findings of this study. As such, there is need for the key stakeholders in biogas technology to sensitize the public on the potential of biogas energy in improving their livelihoods.

\subsubsection{Negative Attitude towards Biogas Technology}

Some of the farmers who have not accessed biogas technology had the perception that biogas is a dirty thing since it is produced from animal waste. However, on observing a functional biodigester, many households were motivated to adopt the technology. Experimentation and visible results lower uncertainty and also stimulate peer discussion of a new idea. In some rural communities, uncertainty of potential adopters on the actual viability of the technology has been a barrier. Without first-hand information or being able to see or try out the technology within the community, farmers are skeptical about committing themselves to something they have only heard of in theory and therefore do not show as much enthusiasm.

Furthermore, negative publicity of biogas technology is as a result of poorly functioning biodigesters can be a major hurdle faced by the biogas technology technicians (masons) in promoting the technology. One key barrier in the development and dissemination of biogas technology in many developing countries is wrong operation and poor maintenance by the users creating a bad image of the technology to non-users (Walekhwa et al., 2010).

\section{Conclusions}

This study has shown that firewood and charcoal still remain the main sources of cooking energy in the study areas despite the enormous potential for the development of biogas through the use of cattle manure and other organic wastes. Even though the use of biogas technology is in its infancy in the study areas, it has shown its potential to have significant impacts on the livelihoods of the adopters. Biogas provides households with cooking energy, saves money spent on conventional energy sources as well as saves time spent on fetching conventional energy sources like wood fuel. Households that have adopted biogas technology also derive health and environmental benefits 
given that biogas is a relatively clean energy source as compared to the wood fuels. Biogas technology can also be used as an income generating activity through the sale of bio-slurry by some of the farmers. Despite the advantages or benefits associated with utilization of biogas, very few households have adopted the technology in the study areas. There are several reasons ascribed to this. Some of the challenges that negatively affect the adoption of biogas technology are high biodigester installation costs; lack of credit facilities to facilitate construction of biodigestors; inadequate numbers of mason or technicians to construct biodigesters; and lack of awareness and or limited information on biogas technology among the farmers.

\section{Recommendations}

In view of the major findings from this study, the following recommendations are made for actions to be taken in order to promote and raise levels of adoption of biogas technology as an alternative energy source for rural populations in Zambia:

More efforts should be directed to sensitizing households on the benefits of biogas technology. There is still a limited awareness about the economic, social and environmental benefits of biogas, hence there is need for educational and awareness campaigns on the benefits of biogas at the local level. This can be done through the combined efforts of the government through the line ministry extension services, private sector and NGOs such as SNV. Most of the potential biodigester adopters do not have sound or adequate technical knowledge about biogas technology that limits them from adopting the technology.

Lack of access to credit facilities is a major bottleneck to adoption of biogas digesters among potential users. The households in rural areas should therefore be encouraged to form and join community based organizations (CBOs). Based on member contributions, these organizations can offer credit and saving services to its members to assist them in construction of biodigesters. The CBOs can also serve as focal points for training members on biogas technology. The community based organizations can even organize self-help activities or projects and construct community based biodigesters to serve a number of households in a locality. Micro-finance institutions, local farmers' associations and savings groups can also play a vital role in providing affordable low interest loans for interested farmers.

There is also need to train at local level, adequate numbers of biogas technicians on the different biogas designs, maintenance and repairs of biogas plants to create a pool of qualified technicians at the local level. The presence of trained biogas technicians would lessen construction costs, mistakes and improper feeding of digesters among the users.

\section{Acknowledgements}

I would like to thank the SNV (Netherlands Development Organization) for funding this research project.

\section{References}

Bhat, P. R., Chanakya, H. N., \& Ravindranath, N. H. (2001). Biogas plant dissemination: success story of Sirsi, India. Energy for Sustainable Development, 5(1), 39-46. http://doi.org/10.1016/S0973-0826(09)60019-3

Brown, V. J. (2006). Biogas: A bright idea for Africa. Environmental Health Perspectives, 114(5), A301-A303

Central Statistical Office (CSO). (2004). 2000 Census of Population and Housing: Volume 11- National Descriptive Tables. Central Statistical Office, Lusaka, Zambia. Retrieved from http://www.zamstats.gov.zm (Retrieved on March 12, 2019)

Flavin, C., \& Aeck, M. H. (2005). Energy for development: The Potential Role of Renewable Energy in meeting the Millenium Development goals. World Watch Institute. Retrieved from http://www.worldwatch.org/system/files/ren21-1.pdf

Government of the Republic of Zambia (GRZ). (2006). Fifth National Development Plan: 2006-2010. Ministry of Finance and National Planning, Lusaka. Retrieved March 10, 2019, from http://evaw-globaldatabase.unwomen.org//media/files/un\%20women/vaw/full\%20text/africa/zambia\%20-\%20fifth\%20national\%20development\%20 plan\%202006-2010.pdf?vs $=1508$

Government of the Republic of Zambia (GRZ). (2008). National Energy Policy. Ministry of Energy and Water Development, Lusaka. Retrieved from http://www.moe.gov.zm/download/policies/The-National-EnergyPolicy-2008.pdf

Government of the Republic of Zambia (GRZ). (2011). Sixth National Development Plan: 2011-2015. Ministry of Finance and National Planning, Lusaka. Retrieved from 
https://siteresources.worldbank.org/INTZAMBIA/Resources/SNDP_Final_Draft_20_01_2011.pdf

Hazra, S., Lewis, J., Das, I., \& Singha, A. K. (2013). Adoption and Use of Improved Stoves and Biogas Plants in Rural India. SANDEE Working Papers, ISSN 1893-1891; WP 86-14. Retrieved from http://www.sandeeonline.org/uploads/documents/publication/1037_PUB_Working_Paper_86_Somnath.pdf

Kabir, H., Yegbemey, R. N., \& Bauer, S. (2013). Factors determinant of biogas adoption in Bangladesh. Renewable Energy Review, 28, 881-889. Retrieved from http://www.sciencedirect.com/science/article/pii/S1364032113005868

Kalinda, T., \& Chisanga, B. (2014). Sugar Value Chain in Zambia: An Assessment of the Growth Opportunities and Challenges. Asian Journal of Agricultural Sciences, 6(1), 6-15. Retrieved from http://maxwellsci.com/print/ajas/v6-6-15.pdf

Kalinda, T., \& Tembo, R. (2010). Sexual Practices and Levirate Marriages in Mansa District of Zambia. Electronic Journal of Human Sexuality, 13. Retrieved from http://www.ejhs.org

Lekule, F. P. (1996). Technologies for improving the wellbeing of rural women in Tanzania. Final report submitted to FAO/SIDA Farming Systems Programme.

Momanyi, R. K., Ong'ayo, A. H., \& Benards, O. (2016). Social-Economic Factors Influencing Biogas Technology Adoption among Households in Kilifi County-Kenya. Journal of Energy Technologies and Policy, 6(6), 2033. Retrieved from https://pdfs.semanticscholar.org/c640/c6c114bf97c90156119f16f56d4270b95c97.pdf

Mwitwa, J., \& Makano, A. (2012). Preliminary Charcoal Production Supply and Demand Assessment in Eastern and Lusaka Provinces. Lusaka, Zambia: USAID.

Policy Monitoring and Research Centre (PMRC). (2013) The-State-of-the-Energy-Sector-in-Zambia. Retrieved from http://www.pmrczambia.com/wp-content/uploads/2015/06/The-State-of-the-Energy-Sector-inZambia-.pdf (Retrieved on March 10, 2019)

Quadir, S.A., Mathur, S. S., \& Kandpal, T. C. (1995). Barriers to dissemination of renewable energy technologies for cooking. Energy Conversion and Management, 36(12), 1129-1132. Retrieved from https://www.sciencedirect.com/journal/energy-conversion-and-management/vol/36/issue/12

SNV. (2013). SNV in Africa People, Partnerships, Progress. Retrieved from http://www.snv.org/public/cms/sites/default/files/explore/download/snv_people_partnership_progress_2013 .pdf

SNV. (2015). Annual Report 2015. Retrieved from http://www.snv.org/public/cms/sites/default/files/explore/download/snv_corporate_annual_report_2015_0.p df

UNDP. (1997). Energy after Rio: Prospects and Challenges. Retrieved from http://www.hubrural.org/IMG/pdf/pnud_energy_after_rio.pdf

USDA. (2014). Feed Enhancement for Ethiopian Development Phase II (FEED II) Project: Baseline Report. ACDI/VOCA.

Walekhwa, P. N., Mugisha, J., \& Drake, L. (2009). Biogas energy from family-sized digesters in Uganda: Critical $\begin{array}{lllll}\text { factors and policy implications. Energy Policy, 37(7), 2754-2762. } & \text {. }\end{array}$ https://doi.org/10.1016/j.enpol.2009.03.018

World Bank. (2011). Household cookstoves, environment, health, and climate change: A new look at an old problem. Washington, DC: World Bank. Retrieved from https://www.cleancookingalliance.org/binarydata/RESOURCE/file/000/000/79-1.pdf

\section{Note}

Note 1. ZMW is the Zambian Kwacha which is the official currency. The exchange rate at the time of the study was 1 US\$ = ZMW10.31

\section{Copyrights}

Copyright for this article is retained by the author(s), with first publication rights granted to the journal.

This is an open-access article distributed under the terms and conditions of the Creative Commons Attribution license (http://creativecommons.org/licenses/by/4.0/). 